\title{
Benlate-induced Instability of Aspergillus Diploids
}

Benonyl is the proprietary name of the fungicide in which the active ingredient is benlate (methyl I-(butyl carbamoyl)-2-benzimidazole carbamate). After extensive trials over the past fow ycars it has beon widely reported to be effective in controlling many phytopathogenic fungi and was released for commercial use in 1969. I wish to draw attention to experiments with Aspergillus nidulans which show that benlate radically alters the stability of diploid strains.

Heterozygous diploid strains of $A$. nidulans are easily selected $^{1}$ and oceasionally form new diploid and haploid genotypes during vegetative growth ${ }^{2}$. These spontaneous segregants are formed after mitotic recombination and mitotic non-disjunction, and their occurrence is visually detectable in diploids heterozygous for genes controlling conidial colour. Segregants appear as distinctly coloured sectors in colonies grown from single uninucleate conidia. The diploid strain used in the experiments with benlate had green conidia, and because it was heterozygous for two genes

$$
\left(\frac{W}{+} \frac{Y}{y}\right)
$$

affecting conidial colour both white and yellow segregants could be recognized. Conidia of this diploid genotype were spread on complete medium, and on complete medium containing bonlate at the concentrations given in Table 1 . Survival was estimated as the number of conidia which formed colonies, and colonies were scored as segregating if they contained either white or yellow sectors.

Table 1. EFFECT OF IBENLATE ON SCRVIVAL AND SEGREGATION OF A DIPLOID A spergillus (bi-1 w(Y)/ad-9 methA-17 y)

\section{Treatment}

Control (no benlate) 0.25 p.p.m. benlate

0.5 p.p.m. benlate

Numbers are means of four replicates. Concentrations are given in parts per million. The gene symbols arc those in regular use.

Besides inhibiting colony formation, benlate also markedly reduced the size of the colonies formed at the highest concentration. The sectors (segregants) were not only more numerous on the benlate containing media but also occupied a much larger area of the colony, indicating that in the presence of benlate the segregational evonts occurred earlier in the growth of the colony. Indeed, most of the spontaneous sectors consisted of only a few conidiophores. Further investigation showed that few of the spontaneous segregants were haploid $(5 / 36)$, and that a larger proportion of segregants formed on 0.5 p.p.m. benlate were haploid (33/72). The corresponding proportions of haploid segregants from another diploid were respectively $3 / 26$ and 48/51. Apparently benlate not only induced the formation of segregants but also significantly increased the proportion of haploid segregants. Benlate-induced sectoring was not detected in haploid strains, and no benlate-induced reversions of auxotrophic mutants were detected in the same strains. These results suggest that benlate may not cause gene mutations.

The effect of benlate is at least superficially similar to the induction of haploidization in Aspergillus diploids by $p$-fluorophenylalanine ${ }^{3}$. This is an antimetabolite of phenylalanine and its incorporation into cell proteins ${ }^{4,5}$ is perhaps responsible for its production of aberrant spindles in dividing human cells $s^{6}$. Thus $p$-fluorophenylalanine is probably directly involved with chromosome segregation. Benlate may also operate directly on chromosome segregation, but its very different molecular structure indicates a different primary metabolic action. Mutagens that break chromosomes also cause instability of Aspergillus diploids ${ }^{7,8}$. Kafer ${ }^{8}$ postulates that these have an indirect effect on stability. Chromosome breakage leads to the formation of nuclei hemizygous for the respective chromosome regions at subsequent nuclear divisions, and these nuclei are potentially unstable. Whatever the primary action of bonlate, it evidently has genetic consequences in Aspergillus. Searches for possible cytological and genetical effects in other specics are required in view of the likelihood that benlate will be widely used in agriculture. I have seen no reports of relevant experiments.

\section{A. C. Hastie}

Department of Biological Sciences,

University of Dundee.

Received December 22, 1969; revised January 30, 1970.

${ }^{1}$ Roper, J. A., Experientia, 8, 14 (1952).

2 Pontecorvo, G., Ann. Rev. Microbiol., 10, 393 (1956).

${ }^{3}$ Lhoas, P., Nature, 190, 174 (1961).

'Vaughan, M., and Steinberg, D., Biochim. Biophys. Acta, 40, 230 (1060).

${ }^{5}$ Westhead, E. W., and Boyer, P. D., Biochim. Biophys. Acta, 54, 145 (1961).

- Biescle, J. J., and Jacquez, J. A., Ann. NY Acad. Sci., 58, 1276 (1954).

7 Fratello, B., Morpurgo, G., and Sermonti, G., Genetics, 45, 785 (1960).

${ }^{8}$ Kafer, E., Genetics, 48, 27 (1963).

\section{Inhibition of Nematode Infestation of Wheat Seedlings by Polygonum hydropiper}

Some nematode diseases of crop plants are ameliorated by Brassica, Tagetes or Asparagus grown previously or concurrently in the same soil ${ }^{1-5}$. Toxic principles within their roots or exuded into the soil are thought to be responsible. Having observed that leaf and root extracts of Polygonum hydropiper L. have nematostatic properties against Rhabditis and other soil nematodes in vitro ${ }^{6}$, I decided to study its effect on wheat disease caused by the wheat gall nematode, Anguina tritici.

Wheat seeds (variety "Red Coat") were surface sterilized, germinated at room temperature $\left(28^{\circ} \mathrm{C}\right)$ and each sown in a pot (diameter $25 \mathrm{~cm}$ ) of sterilized sandy soil supplemented with fertilizer. Sixteen seedlings of $P$. hydropiper at the eight or nine leaf stage $(12-15 \mathrm{~cm}$ tall) were washed in distilled water and planted in eight of the pots. After 2 weeks wheat seedlings at the four leaf stage (6 $\mathrm{cm}$ tall) were transferred to all sixteen pots, those with Polygonum receiving two each and the rest four each. Half the pots containing Polygonum and wheat, and half those containing wheat alone, were inoculated with A. tritici (six galls/pot) and the remaining pots served as uninoculated controls. The pots were then soaked in water to soften the galls and release the nematode larvae which, although $10 \mathrm{yr}$ old, contained active larvae. Within 4 weeks of inoculation heart leaves of some wheat seedlings were finely wrinkled and rolled and some stems were bent-symptoms of disease caused by Anguina ${ }^{7}$. After 7 weeks the intensity of disease was assessed. In pots without Polygonum, two wheat seedlings out of the four present were examined at random. Using the Baermann ${ }^{8}$ technique many Anguina larvae were extracted from infested plants.

Table 1. EFFEOT OF $P$. hydropiper ON THE INCIDENCE OF FOLIAGE SYMPTOMS Table 1. EF WHEAT CAUSED BY A. tritici

\begin{tabular}{|c|c|c|c|c|}
\hline Test & $\begin{array}{l}\text { No. of } \\
\text { wheat } \\
\text { plants }\end{array}$ & $\begin{array}{l}\text { Total leaves } \\
\text { of } \\
\text { wheat plant }\end{array}$ & $\begin{array}{l}\text { Healthy } \\
\text { leaves } \\
\text { plant }\end{array}$ & Diseased \\
\hline $\begin{array}{l}\text { Wheat only } \\
\text { uninoculated } \\
\text { inoculated }\end{array}$ & $\begin{array}{l}6^{*} \\
8\end{array}$ & $\begin{array}{c}97 \cdot 8 \\
85 \cdot 0 \pm 12 \cdot 0\end{array}$ & $\stackrel{\text { All }}{54 \cdot 5 \pm 7 \cdot 9}$ & $\begin{array}{l}\text { None } \\
36 \text { per cent }\end{array}$ \\
\hline $\begin{array}{l}\text { Wheat plus Polygonum } \\
\text { uninoculated } \\
\text { inoculated }\end{array}$ & $\begin{array}{l}8 \\
8\end{array}$ & $\begin{array}{c}54 \cdot 0 \\
52 \cdot 6 \pm 6 \cdot 3\end{array}$ & $\underset{54 \cdot 4 \pm 7 \cdot 8}{\text { All }}$ & $\begin{array}{c}\text { None } \\
4 \text { per cent }\end{array}$ \\
\hline
\end{tabular}

